\title{
Serum levels of interleukin-6, tumor necrosis factor-alpha and interferon-gama in infants with and without dengue
}

\author{
Níveis séricos de interleucina-6, fator de necrose tumoral-alfa e \\ interferon-gama em crianças menores de um ano com e sem dengue
}

\author{
Berta Nelly Restrepoํ, Diana María Isaza ${ }^{1,2}$, Clara Lina Salazar ${ }^{1,2}$, Ruth Ramírez ${ }^{1}$, \\ Marta Ospina ${ }^{3}$ and Luis Gonzalo Alvarez ${ }^{2,4}$
}

\begin{abstract}
This study compared the serum levels of IL-6, TNF- $\alpha$ and IFN- $\gamma$, in children under 1 year of age with and without dengue. Sera were collected from a total of 41 children living in the Department of Antioquia, Colombia (27 patients with dengue and 14 controls). The results showed higher cytokine levels in children with dengue than without dengue, with statistically significant differences for IL- 6 and IFN- $\gamma$. No statistically significant differences were found between clinical forms, although IL- 6 and IFN- $\gamma$ levels were higher in dengue fever cases than in dengue hemorrhagic fever cases. On the other hand, TNF- $\alpha$ levels were higher in dengue hemorrhagic fever than in dengue fever. The levels of IL- 6 and TNF- $\alpha$ were higher in secondary infection than in primary infection, although IFN- $\gamma$ levels were higher in primary infection. These results suggest that IL- 6 , TNF- $\alpha$ and IFN- $\gamma$ are involved in dengue infection independently of the clinical form.
\end{abstract}

Key-words: Dengue. IL-6. TNF- $\alpha$. IFN- $\gamma$. Children.

\section{RESUMO}

Este estudo comparou os níveis séricos de IL-6, TNF- $\alpha$ e IFN- $\gamma$, em crianças menores de um ano com e sem dengue. Os soros foram coletados de um total de 41 crianças residentes no Departamento de Antioquia, Colômbia (27 pacientes com dengue e 14 controles). Os resultados mostraram níveis de citoquinas mais elevadas em crianças com dengue do que naquelas sem dengue, com diferenças estatisticamente significativas para IL- 6 and IFN$\gamma$. Não houve diferenças estatisticamente significativas entre formas clínicas, embora os níveis de IL-6 e IFN- $\gamma$ estivessem mais elevados nos casos de febre do dengue que nos casos de febre hemorrágica do dengue. Por outro lado, os níveis de TNF- $\alpha$ estavam mais elevados na febre hemorrágica do dengue que na febre do dengue. Os níveis de IL- 6 and TNF- $\alpha$ estavam mais elevados em infecções secundárias que em infecções primarias, embora os níveis de IFN- $\gamma$ estivessem mais elevados em infecções primárias. Estes resultados sugerem que IL-6, TNF- $\alpha$ e IFN- $\gamma$ estejam envolvidos na infecção do dengue, independentemente da forma clínica.

Palavras-chaves: Dengue. IL- 6 . TNF- $\alpha$. IFN- $\gamma$. Crianças.

Dengue is an acute febrile disease caused by a virus of the genus Flavivirus, family Flaviridae, with four serotypes (DENV-1 through-4) that are transmitted by Aedes mosquitoes. Dengue is currently endemic in 112 countries with about 100 million cases of dengue fever (DF) annually, and 500,000 of dengue hemorrhagic fever (DHF) ${ }^{8}$. According to the World Health Organization (WHO), two fifths of the world's population is at risk of dengue infection ${ }^{26}$. In Colombia, dengue is endemo-epidemic. According to the Colombian Ministry for Social Protection, the average annual numbers of dengue fever and dengue hemorrhagic fever cases between 2000 and 2004 were 48,084 and 4,392, respectively.
Dengue virus infection is asymptomatic in most cases, but may evolve to a relatively mild and benign illness (dengue fever) or severe forms like dengue hemorrhagic fever and dengue shock syndrome (DHF/DSS) ${ }^{8}{ }^{14}$, which are characterized by plasma leakage and homeostasis disorders (thrombocytopenia and hemorrhagic manifestations). These are the result of vascular endothelium alterations ${ }^{2}$.

Several mechanisms have been proposed to explain the severe forms of the dengue virus. They include the virulence of the strain ${ }^{2829}$; antibody-dependent enhancement of infection ${ }^{101731}$, cell-mediated

\footnotetext{
1. Instituto Colombiano de Medicina Tropical - CES, Sabaneta, Antioquia, Colombia. 2. Universidad de Antioquia, Antioquia, Colômbia. 3. Dirección Seccional de Salud de Antioquia, Antioquia, Colombia. 4. Universidad CES, Medellin, Colombia.

Financial support: Instituto Colombiano para el Desarrollo de la Ciencia y la Tecnología "Francisco José de Caldas", COLCIENCIAS. Project n 3256.04-10174.

Address to: Dr ${ }^{a}$ Berta Nelly Restrepo. Instituto Colombiano de Medicina Tropical-CES. Sabaneta. Carrera 43 \# 52 Sur 99, Antioquia, Colombia.

Tel: 574 305-3500; ext: 293; Fax: 574 301-4258

e-mail: brestrepo@ces.edu.co

Recebido para publicação em: 27/11/2006

Aceito em: 28/11/2007
} 
immune response $e^{2223} 30$ and the quantity and type of cytokines produced during infection.

Some authors have suggested that cytokines secreted by dengue-infected monocytes/macrophages play a critical role in the physiopathology of the hemorrhagic type $e^{31121619}$, although there is no consensus about the predominant cytokines produced during infection.

Given the importance of these immunological characteristics, the current study was undertaken to compare the serum levels of the cytokines interleukin 6 (IL-6), tumor necrosis factor- $\alpha$ (TNF- $\alpha$ ) and interferon- $\gamma$ (IFN- $\gamma$ ), in dengue virus-infected children under one year of age and in a control group with similar characteristics but no infection.

\section{MATERIAL AND METHODS}

A cross-sectional study was conducted between January 2000 and December 2002. Twenty-seven (66\%) patients with confirmed dengue infection, as determined using the clinical and laboratory criteria defined by the Pan-American Health Organization (PAHO) ${ }^{25}$, and 14 (34\%) patients without febrile syndrome at the time of sample collection (no dengue infection) were evaluated. Thus, a total of 41 children under one year of age took part in this study, all of them selected from health institutions in the Department of Antioquia, Colombia.

To diagnose dengue cases, two $4 \mathrm{ml}$ peripheral blood samples were taken. The first sample was taken during the acute phase (up to five days after the onset of the symptoms) and the second sample was taken during the convalescent phase ( 15 days after the onset of the symptoms). Dengue illness was confirmed by the detection of IgM antibodies against the dengue virus, using a UMELISA $®$ Dengue IgM commercial test* in both serum samples (i.e. from the acute and convalescent phases). For all children, detection of viral RNA was performed on the acute-phase samples using the technique previously described by Lanciotti ${ }^{20}$. In addition, the acute-phase samples from six children were subjected to virus isolation through cell culturing with the $\mathrm{C} 6 / 36$ mosquito cell line obtained from Aedes albopictus as described by Gubler et $\mathrm{al}^{7}$ and Guzmán et al ${ }^{9}$.

The primary and secondary infections were confirmed according to the non presence (primary infection) or presence (secondary infection) of $\operatorname{Ig} G$ antibodies against the dengue virus in the serum sample of the acute phase, using a commercial test UMELISA® Dengue $\operatorname{Ig} \mathrm{G}^{*}$.

The IL- 6 , TNF- $\alpha$ and IFN- $\gamma$ levels were quantified using the Quantikine ${ }^{\circledR}$ or Quantikine® HS (High Sensitivity) commercial enzyme-linked immunosorbent assay kits (R\&D Systems, Minneapolis, MN, USA), in accordance with the manufacturers' protocols. The patients' sera were rapidly put aside: frozen at $-20^{\circ} \mathrm{C}$ and stored at $-70^{\circ} \mathrm{C}$ at the Colombian Institute for Tropical Medicine, until use.

This study was approved by the Ethics Committee of the ICMT. All participants were volunteers and the persons in charge of the infants gave their informed consent in writing.
Statistical analysis. The information was processed using the Statistical Package for the Social Sciences software (SPSS ${ }^{\circ}$, version 10, Inc 01, Chicago, IL, USA). The standard curve was generated using the optical densities (ODs) of the standards and the results were calculated using the GraphPad Prism software (GraphPad Software, version 3, Inc, San Diego, CA, USA) by interpolation of the ODs that were measured for the samples. Cytokine levels were compared between the evaluation groups using the Mann-Whitney test with a 95\% confidence level. Proportions were compared between groups using the chi-square test. The significance level was set at 0.05 .

\section{RESULTS}

IFN- $\gamma$ levels were measured in all 41 children (27 with dengue infection and 14 healthy individuals). TNF- $\alpha$ levels were measured in 31 infants (24 with dengue infection and 7 healthy individuals) and IL-6 levels were measured in 24 children (17 with dengue infection and 7 healthy individuals). The mean ages of the infants were $6.60 \pm 2.53$ and $6.9 \pm 3.5$ months for children with and without infection, respectively (no statistically significant difference). The percentages of males were $66.6 \%$ and $42.8 \%$ in the infected and healthy groups respectively.

Dengue infection was confirmed by serology in 26 infants and by viral isolation and RT-PCR in one patient in whom serotype 2 was identified. The most frequent clinical form was dengue fever, in $66.7 \%$ (18/27), followed by dengue hemorrhagic fever, in $33.3 \%(9 / 27)$. The most common symptoms and signs were fever (100\%), eruption (41.7\%) and hepatomegaly (25\%). The most common hemorrhagic manifestation was petechiae in $74.1 \%$ of the cases. Melena was observed in three children and each of the following manifestations appeared in two patients: hematemesis, ecchymosis and epistaxis. Another clinical sign was pleural effusion (four cases). Thirteen (48.1\%) children had diarrhea and nine (33.3\%) had coughs. Coinfection was observed in eight children, of whom one had right basal pneumonia, three had bronchitis, three had urinary infection and one had Ascaris lumbricoides. Hospitalization was required in $70.8 \%$ of the cases.

Comparing the clinical form in the DF and DHF cases, it was observed than the mean age was lower among the patients with DHF than among those with $\mathrm{DF}(\mathrm{P}=0.028)$. Dengue hemorrhagic fever cases were found more frequently in females than in males $(61.1 \%$ vs. $38.9 \%, P=0.667)$. Pleural effusion was observed only in the DHF cases $(P=0.011)$. Platelet levels $\left(\right.$ count $\left./ \mathrm{mm}^{3}\right)$ were lower in DHF than in DF ( $\mathrm{P}=0.918)$. Hematocrit (\%) was similar in the two clinical forms. Secondary infection was higher in DF than in DHF, but the difference was not statistically significant (Table 1).

Cytokines. The levels of the three cytokines were higher in the infected group than among the healthy children, and this difference was statistically significant for IL- 6 and IFN $-\gamma$. With regard to clinical form, TNF- $\alpha$ levels were higher in DHF than in DF. On the other hand, IL- 6 and IFN- $\gamma$ levels were higher in DF than in DHF. These differences were not statistically significant (Table 2). 
Table 1 - Clinical and laboratory data for patients with and without dengue infection according to clinical form.

\begin{tabular}{|c|c|c|c|}
\hline Variable & Infants with DF & Infants with DHF & $\begin{array}{l}\text { (DF/DHF) } \\
\mathrm{P} \text { - value }\end{array}$ \\
\hline Age, mean months \pm SD & $7.33 \pm 2.3$ & $5.11 \pm 2.4$ & 0.028 \\
\hline Sex male $\%\left(\mathrm{n}^{0}\right)$ & $61.1(11)$ & $38.9(7)$ & 0.667 \\
\hline Petechiae $\%\left(\mathrm{n}^{0}\right)$ & $61.1(11)$ & $100.0(9)$ & 0.054 \\
\hline Hepatomegaly \% (nº/total) & $44.4(8 / 18)$ & $33.3(3 / 9)$ & 0.692 \\
\hline Pleural effusion \% $\left(\mathrm{n}^{\circ}\right)$ & $0.0(0)$ & $44.4(4)$ & 0.011 \\
\hline Hematocrit $(\%)$ mean \pm SD & $33.8 \pm 4.6$ & $33.72 \pm 5.5$ & 0.971 \\
\hline $\begin{array}{l}\text { Platelet count, cells } 10^{3} / \mathrm{mm} \\
(\text { mean } \pm \text { SD) }\end{array}$ & $72,628 \pm 64,245$ & $68,875 \pm 106,590$ & 0.918 \\
\hline Secondary infection \% ( $\left.\mathrm{n}^{\circ}\right)$ & $61.1(11)$ & $55.6(5)$ & 1.0 \\
\hline Hospitalization \% ( $\left.\mathrm{n}^{\circ}\right)$ & $61.1(11)$ & $88.9(9)$ & 0.201 \\
\hline
\end{tabular}

DF: dengue fever, DHF: dengue hemorrhagic fever.

Table 2 - Summary of the serum levels of IL-6, TNF- $\alpha$ and IFN- $\gamma$ in children under one year of age, according to dengue virus infection and its clinical form.

\begin{tabular}{|c|c|c|c|c|c|c|}
\hline & No dengue & With dengue & & Dengue fever & $\begin{array}{c}\text { Dengue } \\
\text { hemorrhagic fever }\end{array}$ & \\
\hline \multirow{3}{*}{$\begin{array}{l}\text { Cytokines } \\
\text { (pg/ml) }\end{array}$} & $\bar{X} \pm S . D$ & $\bar{X} \pm S . D$ & P-value & $\bar{X} \pm S . D$ & $\bar{X} \pm S . D$ & P-value \\
\hline & $(95 \% \mathrm{CI})$ & $(95 \% \mathrm{CI})$ & & (9h5\% CI) & $(95 \% \mathrm{CI})$ & \\
\hline & $\mathrm{n}^{\underline{0}}$ & $\mathrm{n}^{\underline{0}}$ & & $\mathrm{n}^{\underline{0}}$ & $\mathrm{n}^{\underline{0}}$ & \\
\hline \multirow{3}{*}{ IL-6 } & $1.90 \pm 1.10$ & $5.65 \pm 2.76$ & 0.005 & $6.07 \pm 2.96$ & $4.65 \pm 2.13$ & 0.383 \\
\hline & $(0.87 ; 2.93)$ & $(4.24 ; 7.07)$ & & $(4.19 ; 7.96)$ & $(2.01 ; 7.30)$ & \\
\hline & 7 & 17 & & 12 & 5 & \\
\hline \multirow{3}{*}{ TNF- $\alpha$} & $0.76 \pm 1.01$ & $5.84 \pm 5.23$ & 0.054 & $5.48 \pm 4.89$ & $6.69 \pm 6.33$ & 0.804 \\
\hline & $(-0.17 ; 1.70)$ & $(3.63 ; 8.05)$ & & $(2.97 ; 8.00)$ & $(0.84 ; 12.56)$ & \\
\hline & 7 & 24 & & 17 & 7 & \\
\hline \multirow{3}{*}{ IFN- $\gamma$} & 0.00 & $18.03 \pm 29.37$ & 0.006 & $20.11 \pm 30.90$ & $13.86 \pm 27.29$ & 0.348 \\
\hline & $(0.00 ; 0.00)$ & $(6.41 ; 29.65)$ & & $(4.75 ; 35.49)$ & $(-7.12 ; 34.84)$ & \\
\hline & 14 & 27 & & 18 & 9 & \\
\hline
\end{tabular}

Eleven (40.7\%) and sixteen (59.3\%) patients had primary and secondary infection respectively. The IL- 6 and TNF- $\alpha$ levels were higher in patients with secondary infection, while IFN- $\gamma$ levels were higher in patients with primary infection. Similar trends were observed between DF and DHF cases for the three cytokines. These differences were not statistically significant (Table 3).

Other findings. During the study, three children died as a result of dengue infection (11.1\%). One of them died at the age of five months, presenting TNF- $\alpha$ and IFN- $\gamma$ levels of $19.3 \mathrm{pg} / \mathrm{ml}$ and $14.9 \mathrm{pg} / \mathrm{ml}$, respectively. These levels represented an increase of $233 \%$ for TNF- $\alpha$ and a decrease of $17 \%$ for IFN- $\gamma$, in relation to the mean for these cytokines among all the infants with dengue. The second fatal case was a nine-month-old child with TNF- $\alpha$ and IFN- $\gamma$ levels of $8 \mathrm{pg} / \mathrm{ml}$ and $28.5 \mathrm{pg} / \mathrm{ml}$ respectively, equivalent to increases of $37 \%$ and $58 \%$. For the third case (a five-month-old child) the only cytokine measured was IFN- $\gamma(0 \mathrm{pg} / \mathrm{ml})$.

IL-6 levels were lower in the hospitalized patients than in the outpatient cases, while TNF- $\alpha$ and IFN- $\gamma$ were the other way round, although without statistically significant differences. Moreover, there was a lack of statistical significance for the differences in the cytokine levels between the patients with and without hepatomegaly, and for the patients with and without serous effusion (data not shown).

Table 3 - Serum levels of IL-6, TNF- $\alpha$ and IFN- $\gamma$ in children under one year of age, according to the presence or absence of antibodies against the dengue virus and its clinical form.

\begin{tabular}{|c|c|c|c|c|c|c|c|}
\hline \multirow{2}{*}{$\begin{array}{l}\text { Clinical } \\
\text { form/antibodies }\end{array}$} & \multirow[b]{2}{*}{$\operatorname{IgG}$} & \multicolumn{2}{|c|}{ IL-6 } & \multicolumn{2}{|c|}{ TNF- $\alpha$} & \multicolumn{2}{|c|}{ IFN- $\gamma$} \\
\hline & & $\overline{X_{ \pm}}+S . D$ & P-value & $\bar{X} \pm S . D$ & P-value & $\bar{X} \pm S . D$ & P-value \\
\hline & $\mathrm{IgG}-$ & $5.89 \pm 3.54$ & 1.0 & $4.60 \pm 2.90$ & 0.879 & $26.31 \pm 21.99$ & 0.25 \\
\hline \multirow[t]{2}{*}{ DF } & $\operatorname{Ig} G+$ & $6.20 \pm 3.54$ & & $5.85 \pm 5.58$ & & $18.22 \pm 36.45$ & \\
\hline & IgG - & $4.59 \pm 2.06$ & 1.0 & $3.32 \pm 3.43$ & 0229 & $21.96 \pm 35.54$ & 0.55 \\
\hline \multirow[t]{2}{*}{ DHF } & $\operatorname{Ig} G+$ & $4.75 \pm 3.11$ & & $11.20 \pm 7.03$ & & $3.73 \pm 7.45$ & \\
\hline & IgG - & $5.40 \pm 2.97$ & 1.0 & $3.53 \pm 2.80$ & 0.290 & $23.95 \pm 28.88$ & 0.29 \\
\hline Total & $\operatorname{Ig} G+$ & $5.87 \pm 2.71$ & & $6.41 \pm 5.92$ & & $14.35 \pm 31.70$ & \\
\hline
\end{tabular}

$\bar{X} \pm$ S.D: Mean and Standard Deviation, DF: dengue fever, DHF: dengue hemorrhagic fever. 


\section{DISCUSSION}

The aim of this study was to compare the serum levels of IL- 6 , TNF- $\alpha$ and IFN- $\gamma$ between two groups of patients under one year of age. One group was infected with the dengue virus and the other was considered to comprise healthy individuals (no dengue infection). Cytokines are the molecules responsible for immune response modulation during infection but, in some cases, they may cause inappropriate responses in people. It has been demonstrated that TNF- $\alpha$ can activate endothelial cells and thus participate in the clinical manifestations of DHF/DSS ${ }^{11}$.

In vitro, IFN- $\gamma$ can increase endothelium permeability and activate the expression of $\mathrm{Fc} \gamma$ receptors by monocytes/ macrophages $^{3122}$. Kurane et al, in $1991^{18}$, reported that IFN- $\gamma$ augments dengue virus infection of human monocytic cells and up-regulates the expression of HLA class I and II antigens, which may result in a greater number of infected cells and facilitate the recognition of the dengue virus antigen by dengue virus-specific T cells. IL-6 is an endogenous pyrogen with similar effects on endothelium permeability ${ }^{22}$. Other researchers have found that the highest IL-6 levels occur in the initial stages of the disease, and it is considered to be involved in the development of dengue symptoms. Later, at the time of the shock syndrome, its levels are raised again, thus suggesting that IL-6 levels are correlated with illness severity ${ }^{12} 1327$.

In this study, the levels of the three cytokines were higher in the dengue virus-infected group than in the healthy controls, with statistical significance only for IL- 6 and IFN- $\gamma$. These results are consistent with other studies. Hober et al, $1998^{11}$; Laur et al, $1998^{21}$, and Kittigul et al, $2000^{15}$, found higher TNF- $\alpha$ levels in dengue cases than in controls. Pinto et al, in $1999^{27}$, reported increased IL- 6 and TNF- $\alpha$ serum levels in dengue-infected patients, in comparison with the healthy group. Juffrie et al, in $2001^{13}$, showed similar results for IL-6.

The serum levels of IL- 6 and IFN- $\gamma$ were lower in the infants with DHF than in those with DF, although these differences were not statistically significant. These results are consistent with those reported by Bethell et al, $1998^{1}$, in a study conducted in Vietnam, in which they showed low IL-6 levels for patients in shock. On the other hand, some authors ${ }^{13}$ have found results contrary to those obtained in the present study, such that IL-6 levels in dengue virusinfected patients (grades III and IV) were significantly augmented, in comparison with the controls, as well as differences between the shock and normotensive groups $(\mathrm{p}<0.0001)$. The same authors ${ }^{13}$ reported high levels of IL- 6 the day of the shock, but normal levels before and after. Hober et al, in $1998^{12}$ and Kuno and Bayley ${ }^{16}$ also correlated the levels of this cytokine with illness severity.

One possible explanation for these discrepancies is that IL-6 levels are increased at the beginning of the disease followed by a decreasing tendency until when shock occurs, at which time its levels are raised again ${ }^{12231}$. Thus, the measured levels would be strongly dependent on the day used for sample collection. Regarding IFN- $\gamma$ levels, Kurane et al, in $1991^{18}$ reported similar levels of this cytokine between children with DHF and DF.
The results obtained for TNF- $\alpha$ levels showed that there were higher values for the patients with DHF than for those with DF, which was in agreement with the previous studies conducted by Kittigul et al, 2000 ${ }^{15}$, and Gagnon et al, 2006 ${ }^{6}$.

In the present study, the TNF- $\alpha$ and IL-6 levels were higher in the secondary infection cases, contrary to the results published by Juffrie et $\mathrm{al}^{13}$, who found a greater frequency of high levels of IL-6 in patients with primary infection (19.6\%) than in patients with secondary infection $(10.8 \%)$. Kurane et $\mathrm{al}^{18}$ did not find differences in this respect. Kuno and Bailey, in $1994^{16}$, observed significantly higher levels of IL-6 in hospitalized adults and children than in the outpatient cases, which was contrary to the results obtained in the present study.

In relation to fatal cases, the TNF- $\alpha$ and IFN- $\gamma$ levels did not show good correlations with illness severity. Chen et al, in $2006^{4}$, reported normal levels of these cytokines in adults who died due to dengue infection. Nguyen et al, in $2004^{24}$, reported that there were no differences in either of these cytokines between fatal and non-fatal cases, while there were higher levels of IL- 6 for fatal cases. Unfortunately, those IL-6 levels could not be measured in this study.

Age and sex were observed to have an influence on the clinical form of dengue, in agreement with findings reported in the literature ${ }^{25}$.

In conclusion, this study demonstrated that IL-6, TNF- $\alpha$ and IFN- $\gamma$ are involved in dengue virus infection at the early stages of the disease. However, none of these cytokines appeared to be a good marker for severe infection, since no statistically significant differences were found between the two clinical forms. One possible explanation for these results is the difficulty in fulfilling the whole list of criteria established by PAHO for diagnosing dengue hemorrhagic fever, which may result in some real dengue hemorrhagic fever cases being classified as classical dengue. It must be noted that the differences for which statistical significance was not demonstrated may have been so because of insufficient sample size and that contradictory data in the literature may be related to lack of uniformity on the day used for sample collection. Therefore, more studies must be undertaken for better comprehension of the balance between these circulating cytokines and their effects on the development of the disease.

\section{REFERENCES}

1. Bethell DB, Flobbe K, Cao XT, Day NP, Pham TP, Buurman WA, Cardosa MJ, White NJ, Kwiatkowski D. Pathophysiologic and prognosis role of cytokines in dengue hemorrhagic fever. The Journal of Infectious Diseases 177: 778-780, 1998.

2. Cardier JE, Mariño E, Romano E, Taylor P, Liprandi F, Bosch N, Rothman AL. Proinflammatory factors present in sera from patients with acute dengue infection induce activation and apoptosis of human microvascular endothelial cells: possible roll of TNF- $\alpha$ in endothelial cell damage in dengue. Cytokine 30: 359-365, 2005

3. Chatuverdi UC, Agarwal R, Elbishbishi EA, Mustafa AS. Cytokine cascade in dengue hemorrhagic fever: implications for pathogenesis. FEMS Immunology and Medical Microbiology 28: 183-188, 2000.

4. Chen LC, Lei HY, Liu CC, Shiesh SC, Chen SH, Liu HS, Lin YS, Wang ST, Shyu HW, Yeth TM. Correlation of serum levels of macrophage migration inhibitory factor 
with disease severity and clinical outcome in dengue patients. The American Journal of Tropical Medicine and Hygiene 74:142-147, 2006.

5. Gagnon SJ, Ennis FA, Rothman AL. Bystander target cell lysis and cytokine production by dengue virus-specific human $\mathrm{CD} 4(+)$ cytotoxic T-lymphocyte clones. Journal of Virology 73: 3626-3629, 1999.

6. Gagnon SJ, Mori M, Kurane I, Green S, Vaughn DW, Kalayanarooj S, Suntayakorn S, Ennis FA, Rothman AL. Cytokine Gene Expression and Protein Production in Peripheral Blood Mononuclear Cells of Children With Acute Dengue Virus Infections. Journal of Medical Virology 67: 41-46, 2002.

7. Gubler DJ, Kuno G, Sather GE, Velez M, Oliver A. Use of mosquito cell cultures and specific monoclonal antibodies for routine surveillance of dengue viruses. The American Journal of Tropical Medicine and Hygiene 33: 158-165, 1984.

8. Guha-Sapir D, Schimmer B. Dengue fever: new paradigms for a changing epidemiology. Emerg Themes Epidemiol [online] 2005 [accessed on June 21, 2005] Available from: http://www.ete-online.com/content/2/1/1, 2005.

9. Guzman MG, Kouri G. Advances in dengue diagnosis. Clinical and Diagnostic Laboratory Immunology 3: 627, 1996.

10. Halstead SB. Pathogenesis of dengue. Challenges to molecular biology. Science 238: 476-481, 1988

11. Hober D, Nguyen TL, Shen L, Ha DQ, Huong VT, Benyoucef S, Nguyen TH, Bui TM, Loan HK, Le BL, Bouzidi A, De Groote D, Drouet MT, Deubel V, Wattré P. Tumor necrosis factor alpha levels in plasma and whole-blood culture in dengue-infected patients: relationship between virus detection and pre-existing specific antibodies. Journal of Medical Virology 54: 210-218, 1998.

12. Hober D, Poli L, Roblin B, Gestas P, Chungue E, Granic G, Imbert P, Pecarere JL, Vergez-Pascal R, Wattre P, Maniez-Montreuil M. Serum levels of tumor necrosis factor-alpha (TNF-alpha), interleukin-6 (IL-6), and interleukin-1beta (IL-1beta) in dengue-infected patients. The American Journal of Tropical Medicine and Hygiene 48: 324-331, 1993.

13. Juffrie M, Meer GM, Hack CE, Haasnoot K, Sutaryo, Veerman AJP. Inflammatory mediators in dengue virus infection in children interleukin- 6 and its relation to C-reactive protein and secret phospholipase A2. The American Journal of Tropical Medicine and Hygiene 65: 70-75, 2001.

14. Kautner I, Robinson MJ, Kuhnle U. Dengue virus infection: epidemiology, pathogenesis, clinical presentation, diagnosis and prevention. The Journal of Pediatrics 131: 516-524, 1997.

15. Kittigul L, Temprom W, Sujirarat D, Kittigul C. Determination of tumour necrosis factor-alpha levels in dengue virus infected by sensitive biotin-streptavidin enzymelinked immunosorbent assay. Journal of Virological Methods 90: 51-57, 2000.

16. Kuno G, Bailey RE. Cytokine responses to dengue infection among Puerto Rican patients. Memórias do Instituto Oswaldo Cruz 89: 179-182, 1994.

17. Kurane I, Ennis FA. Immunopathogenesis of dengue virus infections. In: Gubler DJ, Kuno G (eds) Dengue and Dengue Hemorrhagic Fever. CAB International, London p. 273-290, 1997.
18. Kurane I, Innis BL, Nimmannitya S, Nisalak A, Meager A, Janus J, Ennis FA Activation of T Lymphocytes in Dengue Virus Infections. High Levels of Soluble Interleukin 2 Receptor, Soluble CD4, Soluble CD8, Interleukin 2 and Interferongamma in Sera in Children with Dengue. The Journal of Clinical Investigation 88: 1473-1480, 1991.

19. Kurane I, Meager A, Ennis FA. Induction of interferon alpha and gamma from human lymphocytes bye dengue virus-infected cells. The Journal of General Virology 67(pt 8): 1653-1661, 1986

20. Lanciotti RS, Calisher CH, Gubler DJ, Chang GF, Vorndam V. Rapid detection and typing of dengue from clinical samples by using reverse transcriptase-polymerase chain reaction. Journal of Clinical Microbiology 30: 545-551, 1992.

21. Laur F, Murgue B, Deparis X, Roche C, Cassar O, Chunge E. Plasma levels of tumour necrosis factor alpha and transforming growth factor beta-1 in children with dengue 2 virus infection in French Polynesia. Transactions of the Roval Society of Tropical Medicine and Hygiene 92: 654-656, 1998.

22. Malavige GN, Fernando S, Fernando DJ. Seneviratne SL. Dengue viral infections. Postgraduate Medical Journal 80: 588-601, 2004.

23. Mentor NA, Kurane I. Dengue virus infection of human T lymphocytes. Acta Virologica 41: 175-176, 1997.

24. Nguyen TH, Lei HY, Nguyen TL, Lin YS, Huang KJ, Le BL, Lin CF, Yeh TM, Do QH, Vu TQ, Chen LC, Huang JH, Lam TM, Liu CC, Halstead SB. Dengue hemorrhagic fever in infants: a study of clinical and cytokine profiles. Journal of Infectious Diseases 189: 221-232, 2004

25. Organización Panamericana de la Salud. Dengue y dengue hemorrágico en las Américas: guías para su prevención y control. Publicación Científica n ${ }^{0} 548$, 1995.

26. Pan American Health Organization. Plan Continental de Ampliación e Intensificación del Combate al Aedes aegypti: Informe de un grupo de trabajo. [online] [accessed on Sep 28, 2006]. Available from: http://www.paho.org/ Spanish/AD/DPC/CD/doc407.pdf, 2006.

27. Pinto LM, Oliveira SO, Braga EL, Nogueira RM, Kubelka CF. Increased Proinflammatory Cytokines (TNF-alpha and IL-6) and Anti-inflammatory Compounds (sTNFRp55 and sTNFRp75 in Brazilian Patients during Exanthematic Dengue fever. Memórias do Instituto Oswaldo Cruz 94: 387-394, 1999.

28. Rico-Hesse R, Harrison LM, Salas RA, Tovar D, Nisalak A, Ramos C, Boshell J, Mesa MT, Nogueira RM, Rosa AT. Origins of dengue type 2 viruses associated with increased pathogenicity in the Americas. Virology 230: 244-251, 1997.

29. Rosen L. The emperor's New Cloths revisited or reflections on the pathogenesis of dengue hemorrhagic fever. The American Journal of Tropical Medicine and Hygiene 26: 337-343, 1997.

30. Rothman AL. Immunology and Immunopathogenesis of dengue disease. Advances in Virus Research 60: 397-419, 2003.

31. Rothman AL, Ennis FA. Immunopathogenesis of dengue hemorrhagic fever Virology 257: 1-6, 1999. 